\title{
Muslim Society Perception of The Unregistered Divorce
}

\author{
Lutfi $^{*}$, Muhammad Akbar ${ }^{2}$, Marzuki Marzuki ${ }^{3}$ \\ ${ }^{1}$ Islamic Family Law Department, Postgraduate, Institut Agama Islam Negeri Palu \\ 2 Islamic Family Law Department, Postgraduate, Institut Agama Islam Negeri Palu \\ ${ }^{3}$ Islamic Family Law Department, Postgraduate, Institut Agama Islam Negeri Palu
}

\begin{abstract}
The aim of this paper is to discuss the view of Muslim people in

Marawola, district of Sigi, towards unregistered divorce. This study uses qualitative methods and data was gathered through observation, in-depth interviews, and written material. Data analysis was analyzed using grounded theory approach. The results showed that the understanding and view of the Marawola community towards unregistered divorce was that of divorce carried out outside a religious court involving only husband and wife and religious leaders. On other occasions, it also involved village officials, where the divorce was only confirmed by a letter of freedom signed by the husband and wife, two witnesses and sometimes also signed by the village head as the one who knew.
\end{abstract}

ARTICLE

INFORMATION

Keywords: Unregistered divorce, society understading, Marawola district 


\section{Introduction}

In the Indonesian Dictionary, divorce means separation, breaking up the relationship between husband and wife. ${ }^{1}$ In its implementation, legal norms are needed to regulate this case because divorce is an essential element in deciding and ending a marriage relationship in order to regulate rights, obligations, and responsibilities of each husband and wife, in order to get justice as fairly as possible before the law. Divorce for Muslims is better known as talaq. ${ }^{2}$ According to Sayyid Sabiq, talaq is "releasing the marriage bond or breaking the marriage relationship". ${ }^{3}$

According to Fuad Said, what is meant by divorce is the breaking of the marriage between husband and wife because there is no harmony in the household or other reasons such as the infertility of the wife or husband, and this is carried out after previously striving for peace by involving the families of both parties. ${ }^{4}$

Divorce is the last solution in the settlement of domestic problems, after previously mediation is done by both

${ }^{1}$ http:// kamusbahasaindonesia.org/cerai KamusBahasaIndonesia.org. (diakses pada 02 Apri 2019)

2 See Rusli Rusli, "Hermeneutical Reading of Țalāq," HUNAFA: Jurnal Studia Islamika 12, no. 2 (2016): 209-229.

${ }^{3}$ Quoted in Abdul Manan, Problematika

Perceraian Karena Zina dalam Proses Penyelesaian Perkara di Lingkungan Peradilan Agama, Mimbar Hukum No 52 Th XII Mei- Juni 2001, Jakarta, al-hikmah \& DITBINBAPERA Islam

${ }^{4}$ Cited in Rifyal Kabah, Permasalahan Perkawinan, Varia Peradilan No. 271 Th XXII Juni 2008, Jakarta, IKAHI . parties involving the noble parties, such as religious leaders, family leaders, community leaders, traditional leaders, up to the court to find a peaceful way to reconcile both parties to maintain the integrity and unity of their household.

However, when mediation is deemed incapable of contributing to produce an agreed solution that can reconcile the two parties between husband and wife, then divorce is a way out to end the domestic turmoil and conflict that occurs, for the benefit of both parties.

The Quran, on many occasions, often advises both husband and wife not to conclude divorce on trivial causes, and recommends that husband and wife interact well. The Qur'an also recommends husband and wife to be more patient when facing various kinds of household problems, be good between each other for the sake of harmony in the household, not easily provoked by emotions, and putting priority on peace efforts when a conflict occurs by sending a fair mediator from both parties. This is because household breakdowns can affect children, which has the potential to create tension and conflict in the community. ${ }^{5}$

Broadly speaking, there are several forms of divorce. Djamil Latif made the classification of divorce, among others: 6 divorce that occurs by a judge's decision, namely liân; divorce because of the

${ }^{5}$ See more detailed Rusli Rusli, "The Role of Family in Preventing Social Conflict in Society From Islamic Perspectives," HUNAFA: Jurnal Studia Islamika 17, no. 1 (2020): 108-122.

6 M. Djamil Latif, Hukum Perceraian di Indonesia. (Graha Indonesia: 1981),163

e-ISSN: 2715-4580

p-ISSN: 2715-8268 
husband's disgrace such as impotence, and because the husband refuses to convert to Islam; talak that occurs without a judge's decision, that is, ordinary divorce, that is pronounced by the husband, both clear (sharih) and insinuation (kinayah); fasakh, that occurs with a judge's decision, namely because of the reason that a boy or girl is still under age, and the marriage is not carried out by a guardian; fasakh because such reasons as insanity, unequality, lack of a dowry of mahar mitsil, and one party refused to convert to Islam; finally, fasakh that occurred without a judge's decision, due to the reason for the independence of the wife, marriage relationship between husband and wife, and the marriage was damaged from the start. ${ }^{7}$

Divorce should require legality from a religious court for a husband and wife who are Muslim, as regulated by Marriage Law number 1 of 1974 and the Islamic Law Compilation (KHI). However, the understanding and awareness of the public to comply with laws and regulations is still relatively lacking, in addition to the lack of legal socialization, far distance to the religious court office, and also a lack of understanding of religious law, where they think that divorce in a religious court is a divorce from the government and just administrative process. Therefore, many married couples who wish to divorce do not implement it based on the prevailing laws or regulations; or in other words, they are doing unregistered divorce.

${ }^{7}$ Taufiq, Peradilan Keluarga Indonesia (Jakarta: Mahkamah Agung RI, 2001), 80
As a researcher, the writer goes directly to the community both in conducting research and other socioreligious activities. From there, the authors get a lot of information that unregistered divorce occurs a lot in the District of Marawola. This was revealed based on community reports that a number of them did not have a marriage book because they had previously been legally married and registered at the religious affairs office. However, because their marriage ended, they did unregistered divorce. This makes marriage registration difficult. As a result, their second marriage could not be registered and they could not have a Marriage Certificate.

As for the process of unregistered divorce, it is only carried out in the presence of family figures, religious leaders, traditional leaders, and is witnessed by village government officials and strengthened through a piece of paper in the form of a Freedom Letter which is signed on a stamp by the two parties who are going to divorce, witnessed by two witnesses and recognized by the local village head.

\section{Literature Review}

\subsection{Definition of Divorce in Islam}

Divorce is part of household dynamics. Divorce exists because of marriage. Although the purpose of marriage is not divorce, divorce is law of nature, with different causes, including the death of the husband, quarrels between husband and wife.

Soemiyati explained that in carrying out life, husband and wife are e-ISSN: 2715-4580 p-ISSN: 2715-8268 
not always in a peaceful and peaceful situation, but sometimes there are misunderstandings between them, or one of the parties neglects their obligations, does not trust each other. If a marriage is continued, the formation of a peaceful household as desired by religion will not be achieved. In addition, it is also feared that the separation of husband and wife will result in a split between the two parties, so Islam requires divorce as a last resort for husband and wife who have failed to build a household. ${ }^{8}$

Even though Islamic teachings justify a husband to drop divorce, it must be remembered that divorce is a lawful act which has been hated by Allah. In a Hadith, it is stated that Allah SWT hates divorce which is dropped without any urgent purpose. The Prophet Muhammad said:

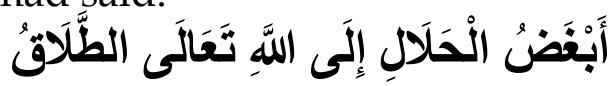

"A lawful act which has been hated by Allah is divorce" 9

From the hadith above, it is explained that divorce is lawful, but is hated by Allah. Divorce can be carried out if it is based on defensible grounds, and it is the last resort taken by the husband and wife if they have made various efforts to resolve it, but cannot restore the integrity and harmony of the husband and wife's household life. There are many negative effects of divorce, not only on the husband or wife, but also on the lives of their children. Therefore,

${ }^{8}$ Muhammad Syaifuddin dkk, Hukum Perceraian (Jakarta: Sinar Grafika, 2013), 21.

9Sunan Abu Dawud bin Al-Syaiys bin Ishaq, Sunan Abi Dawud, vol. 1 (Beirut: Dar alFikr,1994), 500 divorce is not the main solution for husband and wife relationships.

Zainudin ibn Syekh Abdul Aziz defines talaq as a way of breaking the marriage contract with certain words. ${ }^{10}$ This opinion is almost similar to the opinion expressed by Sheikh Muhamad bin Qosim Al Ghozy in his book entitled Fathul Qorieb.11

In the Islamic Law Compilation, the meaning of talaq is contained in Article 117 which states, "Divorce is a husband's pledge before a Religious Court hearing which is one of the causes of divorce". Based on some of the definitions and opinions above, it can be concluded that divorce is the dissolution of the marriage bond between husband and wife by using the word talaq and the like, which eliminates the lawful relationship between husband and wife.

\subsection{Divorce in Regulations}

In Indonesia, divorce is regulated in the Marriage Law No. 1 of 1974. Prior to that, marriage was regulated in Book I of the Civil Code including provisions concerning the break up of marriage (divorce). ${ }^{12}$

${ }^{10 Z a i n u d i n ~ i b n u ~ S y e k h ~ A b d u l ~ A z i z, ~}$ Fathul Mu'in, translated by Ali As'ad (Surabaya: Al Hidayah, 1979), 135.

${ }^{11}$ Syekh Muhamad bin Qosim Al Ghozy, Fathul Qorieb, vol. 2, translated by Ahmad Sunarto (Surabaya: Al-Hidayah, 1992), 63.

${ }^{12}$ Sukaenah, S., Rusli, R., \& B, M. T. (2020). The Effectiveness of Indonesia Supreme Court Regulation Number 1 Year 2016 Concerning Mediation of Marriage Disputes INTERNATIONAL JOURNAL OF CONTEMPORARY ISLAMIC LAW AND SOCIETY, 2(1), 63-80. 
With the enactment of the Marriage Law Number 1 of 1974, the provisions in Book I of the Civil Code concerning marriage do not apply. In Book I of the Civil Code (KUH Perdata) and Marriage Law Number 1 of 1974 there is no definition of divorce, but only regulates the break-up of marriage and its consequences. Article 39 of Marriage Law Number 1 of 1974 regulates the dissolution of a marriage, which states that a marriage can break up because death, divorce, and Court's decision. ${ }^{13}$

Meanwhile, according to the Government Regulation Number 9 of 1975 concerning Implementation of Marriage Law Number 1 of 1974 only regulates the procedure for divorce, namely in Article 14 which states that, "a husband who gets married according to Islam, who will divorce his wife, submits a letter to the Court at his place of residence, notifying that he intends to divorce his wife along with the reasons thereof, and asking the Court to hold a hearing for this purpose.

\subsection{Procedures of Divorce}

In the Islamic Law Compilation, it is stated the procedures for divorce.

a. A husband, who is going to divorce his wife, first submits an application in oral or written form to the Religious Court in the area where the wife lives

\footnotetext{
${ }^{13}$ Muslih, I., Nurdin, N., \& Marzuki, M. (2020). Effectiveness of Marriage Services Through Information System Management (SIMKAH) at Palu City Religious Court INTERNATIONAL JOURNAL OF CONTEMPORARY ISLAMIC LAW AND SOCIETY, 2(1), 20-36.
}

with the reasons, and requests that a hearing be held for this purpose (KHI, Article 129).

b. The Religious Court can receive or reject the request for divorce, and the decision can be called for legal action at the level of appeal or cassation (KHI, Article 130).

Furthermore, according to KHI Article 131, the technical settlement of the case for divorce is through the following stages:

a. The Religious Court after studying the application for divorce, in no later than 30 days will summon the peinolion (husband) and his wife to ask for an explanation of everything related to the intention of divorce;

b. After the Religious Court (Judge) failed to advise both parties, and there was sufficient reason to impose divorce, as well as the person concerned could no longer live in harmony in the household, the Religious Court issued a decision regarding the permission for the husband to pledge his divorce;

c. After the decision of the Religious Court has permanent legal force, the husband pledges his divorce before the Religious Court hearing, which is attended by his wife or attorney;

$\mathrm{d}$. If the husband does not make a pledge for divorce within 6 months from the Religious Court's decision regarding the permission for the divorce vows for him to have permanent legal force, then the husband's right to pledge his divorce will be annulled and the marriage bond remains intact; 
e. After the trial for witnessing the pledge of divorce was held, the Religious Court made a decision regarding the occurrence of divorce in fourfold, which was evidence of divorce for the former husband and wife. The first sheet along with the divorce pledge letter is sent to the Registrar of Marriages in the area where the husband lives for registration; the second and third sheets were given to the ex-husband and wife, respectively; and the fourth sheet is kept by the Religious Court.

Thus, divorce, according to the KHI, is one of the causes for the breakdown of a marriage between husband and wife, in addition to other causes such as death or a court decision. A divorce can be imposed by the husband against his wife or on the basis of the wife's lawsuit against her husband.

Reasons for divorce may include one of the parties committed adultery, behaving badly, leaving the other party for two years, being sentenced to five years or more, committing cruelty, physical disabilities, disputes between husband and wife, husbands violation against divorce-ta'lik, and change of religion. The divorce occurred after a decision made by the Religious Court judge, which previously had made a peace effort between husband and wife by the judge, and apparently no agreement was reached.

\section{Methodology}

This study uses qualitative approach investigating Muslim society Marawola district Sigi regency in understanding of the unregistered divorce. Data were collected through observations, in-depth interviews with twenty citizens from the district and shared written documents. The interview last between $30 \mathrm{t} 045$ minutes.

Data analysis consists of several procedures: reduction and verification techniques with various data sources. ${ }^{14}$ ${ }^{15}$ The reduced data is then analyzed reflecting on theoretical concepts used in this study. ${ }^{16}$

\section{Result and Discussion}

\subsection{The public perception of the legal impact of unregistered divorce}

Understanding means "the process, way, act of comprehending, in which he is able to describe what he knows." $17 \mathrm{~A}$ person is considered capable of revealing his world in the form of a frame of mind. Therefore, the emphasis in this research lies in how a person interprets his actions based on the events he had experienced.

The study of understanding is not easy to reveal except by observing in depth and actively engaging in direct

${ }^{14}$ Nurdin, N. (2017a). Research in Online Space: The Use of Social Media for Research Setting Jurnal Sistem Informasi (Journal of Information System), 13(1), 67-77.

${ }^{15}$ Nurdin, N. (2017b). To Research Online or Not to Research Online: Using Internet-Based Research in Islamic Studies Context. Indonesian Journal of Islam and Muslim Societies, 7(1), 31-54.

16 Nurdin, N., \& Yusuf, K. (2020). Knowledge management lifecycle in Islamic bank: the case of syariah banks in Indonesia. International Journal of Knowledge Management Studies, 11(1), 59-80. https://doi.org/10.1504/ijkms.2020.105073

${ }^{17}$ https:/ / kbbi.web.id/tipologi (Accessed 17 July 2019)

e-ISSN: 2715-4580 p-ISSN: 2715-8268 
involvement with objects in the actor's world. In order to obtain as deep information as possible, an appropriate theory is needed to support successful disclosure. This framework is closely related to phenomenology as a way of being able to understand the behavior of under-handed divorce actors. ${ }^{18}$

From the research results, not all Marawola people practice unregistered divorce. Therefore, not everyone can be used as an object to express people's perception of the impact of unregistered divorce. The meaning of unregistered divorce can only be interpreted by the perpetrators based on the knowledge they have. From here, the presence of the researcher as an observer tries to dig up information related to people's perception of the legal impact unregistered divorce in society.

The difference in people's perception of the divorce law in Marawola is also caused by their obligation to be loyal to a religious law. Faithfulness to this law then leads them to practice something they believe in, even though this will have an impact on neglecting state law. Therefore, it is not uncommon for this behavior to be considered a form of violation and noncompliance with the law.

The diversity of perceptions in the community's point of view implies a different level of understanding of religious law. The understanding of the perpetrator towards unregistered divorce

18 For more details see Rusli Rusli, "Pendekatan Fenomenologi Dalam Studi Agama Konsep, Kritik Dan Aplikasi," Islamica: Jurnal Studi Keislaman 2, no. 2 (2008): 141-153. is an individual's awareness that is expressed in his perception. Based on the theoretical framework that has been described previously, the authors found a suitable trait between the phenomenon of unregistered divorce and the theoretical framework. From the perceptions developed by the Marawola community, it can be identified and classified into two groups, namely those who follow textual Islamic ideas and those who follow contextualist jurisprudence. The two typologies do not mean that each is independent and disconnected from the other, nor is it permanent. However, it would be more appropriate to say that it is a prominent trend of understanding, considering that each typology has interrelated characteristics.

As stated by Zed, Head of the Office of Religious Affairs.

For the most part, Marawola community still differentiates between religious law and government law. They consider that the divorce is legal even if it is only carried out according to religion. For them, this government regulation has absolutely nothing to do with religion. Government regulations only regulate the recording process, or in other words, just legalization. Therefore, we need a strict formulation through regulations that include fatwas, that government decisions are part of the pillar of divorce that must be implemented. ${ }^{19}$

${ }^{19}$ Interview with Zed, Head of Religious Office, Marawola, 7 August 2019

e-ISSN: $2715-4580$ p-ISSN: 2715-8268 


\subsection{Public Perception of Unregistered Divorce \\ Of the 14 informants, data were} found on the various backgrounds of those who carried out a unregistered divorce. From the data, it can be concluded that one of the people's point of view regarding unregistered divorce is that they think that the way and solution to unregistered marriage is unregistered divorce as well.

The author found evidence from the interviews with informants, that unregistered divorce was partly because when he got married, he did it in a sirri manner, that is, it is not registered in the Office of Religious Affairs. The perpetrator understands that a man and woman who want to divorce, while they are constrained by their unregistered marital status, they may divorce under their hands too. As Wiwin said,

Logically, if a sirri marriage is valid, then sirri divorce is also valid, because the marriage is unregistered, so the divorce must also be carried out in underhanded way. It is different if the marriage is done in formal way, then the divorce must also be carried out before the Religious Court. So logically, we do not need to make it complicated. ${ }^{20}$

It can be understood that this view emerged because of differentiating divorce procedures based on marital status. That is, an underhand divorce is only legal for those whose marriage was carried out in an underhanded way. June 2019.
${ }^{20}$ Interview with Wiwin, Marawola 16
Meanwhile, divorce for those who are legally married is only legal if it is carried out before the Religious Court. Thus, the conclusion that can be drawn from the informant's point of view is that whether or not a divorce is legal depends on the form of the marital status.

They, with full confidence, will make and carry out decisions according to the way they think and based on the practices that have been done by people before them. As is well known, most of the Marawola people have a habit of making decisions regarding marriage and divorce through consultation with religious and traditional leaders, because this has become a common practice among the community. Especially for people in their environment, they make previous practices as references in their action regarding divorce.

Their understanding of underhand divorce is obtained from the explanation of religious leaders in various times and opportunities directly, which is then amplified from the internet through the lectures and the articles they read. Thus, it can be understood that a person's bigotry towards a figure and the environment greatly affects one's perception and behavior.

In the author's view, this understanding will lead to a gap that separates state law and Islamic law. In addition, if such a divorce is carried out massively, it will create legal uncertainty, even though the law has explicitly instructed the public to divorce before a court, regardless of their marital status, whether their marriages were formal or underhanded. Therefore, a divorce 
carried out under this provision cannot be applied and served as a legal guideline.

\subsection{Perception of Community Following Contextual Religious Legal Views \\ Contextualist society can be} understood as a group of people who prioritizes the context of the problems that are happening in society. This group places figh as the result of human thought in order to describe descriptively the laws of Allah and the Sunnah of the prophet. It does not rule out that there are things that have not been revealed during the formation of figh, while in subsequent periods there are new things. This raises the view that figh must be rebuilt in accordance with the conditions of society.

This type of group uses the ability of reason as a method to assess whether figh texts are still relevant to this condition. Therefore, if the rules in figh are not in accordance with the times, they must be renewed. In fact, if necessary they would leave the old figh and replace it with a new one.

The characteristic that can be seen in this group lies in the enthusiasm for reconstructing the substantive values of figh. They always consider the conditions under which the rule of law in figh is born. They tried to understand the meaning of sharia with a substantive approach, outside the narrative text, such as the background of the text, the benefits needed by the people, social context, customs and benefits and disadvantages. This approach is put on priority in this group, so that they no longer dwell on legal textualities that previously originated in figh. ${ }^{21}$

People who follow the concept of contextualist figh suggest that there must be progressive ijtihad in implementing and rebuilding figh, particularly in Islamic family law or gender relations. ${ }^{22}$ The aim is that jurisprudence does not experience stagnation as in the historical development of Islamic law. Therefore it is necessary to develop an orientation and look for the value of the substance of the rules in figh. ${ }^{23}$

Several prominent Islamic law reformers in Indonesia, such as Munawir Sadzali and Ibrahim Hosen, ${ }^{24}$ actually offered this idea in the mid-1980s broadly and clearly. According to Sadzali, in order to maintain the relevance of social teachings of Islam, we should not be fixated on a literal understanding of the verses of the Quran and Hadith, especially fiqh texts. Conversely, one must be more contextual or conditional by prioritizing the essence of the two sources of law above. Besides that, it is also necessary to

${ }^{21}$ Khotimatul Husnul, Penerapan Syari'ah Islam Bercermin pada Sistem Aplikasi Syari'ah Zaman Nabi (Yogyakarta: Pustaka Pelajar, 2007), 51.

22 Rusli Rusli, "An Analysis of Islamic Feminism in Indonesia: Reconstruction of Islamic Legal Issues on Gender Relations," Hunafa: Jurnal Studia Islamika 3, no. 1 (2006): 1-12.

${ }^{23}$ For more explanation on this issue, see Rusli Rusli, Islamic Feminism: Responses of Muslim Feminists to Gender Inequality in Indonesia (Palu: Irshed Press, 2006).

24 See also Rusli Rusli, Nalar Fikih Tradisionalis Progresif: Analisis Terhadap Epistemologi Ibrahim Hosen, 1st ed. (Yogyakarta: Maghza Books, 2014).

e-ISSN: $2715-4580$ p-ISSN: 2715-8268 
foster the belief that Islam is a religion that has a flexible nature. ${ }^{25}$

The contextualization of Islamic laws on marriage in the view of this group is something that must be done, considering the condition of society that requires certainty in marriage or divorce. Therefore, the government and related parties agreed to reformulate the rules regarding marriage. In the decision, it was agreed that divorce for a Muslim could only be done before a Religious Court hearing. This agreement can be considered by the author as the contextualization of Islamic law (figh), in which figh has developed in its practical level.

In Indonesia, the government in this matter has paid attention to the institution of marriage, namely by passing the Marriage Law No. 1 of 1974, which juridically regulates the law of marriage for the people of Indonesia. This law is part of the ideals of the state to create an orderly and just condition of society.

The emergence of this Marriage Law in the midst of society should divert religious leaders, mosque imams, and syara 'officials in Marawola, especially the perpetrators of underhand divorce, to state law. However, this Law does not necessarily eliminate and annul the prevailing religious law traditions. The birth of the Marriage Law is a concrete manifestation of the desire of the community towards a just change but still adhering to fiqh principles. The presence of the marriage law and $\mathrm{KHI}$ is

\footnotetext{
${ }^{25}$ Munawir Sadzali, Ijtihad Kemanusiaan (Jakarta: Paramadina, 1997), 75.
}

expected to be able to answer accusations stating that figh is outdated and shackled by the strong tradition of previous figh traditions of Islamic scholars.

\section{Conclusions}

From the above discussion, it can be concluded that:

First, the perception of the Marawola community regarding underhand divorce is that divorce is carried out outside a religious court by only involving husband and wife and religious leaders. On other occasions, it also involved village officials, where the divorce was only confirmed by a letter of freedom which was signed by the husband and wife, two witnesses and sometimes also signed by the village head as knowing.

Second, the legal impact of unregistered divorce is that the rights of children are neglected, which is clearly contrary to the spirit of Article 41 of the Marriage Law Number 1 of 1974, which states that due to the breakdown of marriage, parents are still obliged to care for and educate their children, solely based on the child's interests; if there is a dispute regarding the tenure of children the court gives its verdict.

\section{REFERENCES}

Abd al-Baqi Fuad Muhammad.al-Mu'jam al- Mufahras li al-Faz al-Quran alKarim. Beirut : Dar al-Fikr, 1987

Abu Dawud, Sunan Abu Dawud, vol. 2, Beirut: Daar al-Kutub, 1996,

Abdul Kadir Muhammad, perkembangan Hukum Keluarga di Beberapa Negara e-ISSN: 2715-4580 p-ISSN: 2715-8268 
International Journal of Contemporary Islamic Law and Society

Vol. 2 No. 2 Tahun 2020

Eropah, Citra Aditya Bakti, Bandung, 1998

Ali Atabik dan A. Zuhdi Muhdor, Kamus

Kontemporer Arab-Indonesia, Multi

Karya Grafika, Yogyakarta, 2003.

Ahmad Warson Munawir, Kamus AlMunawir, Surabaya: Pustaka Progesif, 1997.

Al Ghozy Syekh Muhamad bin Qosim, Fathul Qorieb, vol.2, trans. Ahmad Sunarto, Surabaya: Al-Hidayah, 1992.

Al Hamdani, Risalah Nikah, Jakarta: Pustaka Amani, 2002.

Campbell Tom, Tujuh Teori Sosial Sketsa, Penilaian dan Perbandingan,

Kanisius, Yogyakarta, 1994.

Dahlan A.Aziz, Ensiklopedi Hukum Islam, Jilid 5, PT.Ihtiar Baru Van Hoeve, Jakarta, 1996.

Ghazaly Abd Rahman, Figh Munakahat, Jakarta : Kencana, 2010

Hasan Mustofa, Pengantar Hukum Keluarga, Bandung: Pustaka Setia, 2011.Junus Mahmud, Hukum Perkawinan Islam Menurut Mazhad: Sayfi'I, Hanafi, Maliki dan Hambali. Jakarta : Pustaka Mahmudiyah, 1989.

Imam Taqiyuddin Abu Bakar AlHusaini. Terjemahan Kifayatul Akhyar, Surabaya, Bina Ilmu1997

Kabah Rifyal, Permasalahan Perkawinan , Varia Peradilan No. 271 Th XXII Juni 2008, Jakarta, IKAHI .

Kamal Abu Malik, Fikih sunnah Wanita. Jakarta: Pena Pundi Aksara, 2007

Manan Abdul, Problematika Perceraian Karena Zina dalam Proses Penyelesaian Perkara di Lingkungan Peradilan Agama, Mimbar Hukum No 52 Th XII Mei- Juni 2001,

$\&$ DITBINBAPERA Islam

L. Berger Peter, Invitation to Sociologi: A Humanistic Prospective, alih bahasa Daniel Dhakidae, inti Sarana Aksara, Jakarta, 1992.

Manan Abdul, Reformasi hukum Islam di Indonesia, PT Raja grafindo Persada, Jakarta, 2006

Mudzhar M. Atho, Pendekatan Studi Islam dalam Teori dan Praktek. Yogyakarta: Pustaka Pelajar, 1998.

Muslih, I., Nurdin, N., \& Marzuki, M. (2020). Effectiveness of Marriage Services Through Information System Management (SIMKAH) at Palu City Religious Court INTERNATIONAL JOURNAL OF CONTEMPORARY ISLAMIC LAW AND SOCIETY, 2(1), 20-36.

Nurdin, N. (2017a). Research in Online Space: The Use of Social Media for Research Setting Jurnal Sistem Informasi (Journal of Information System), 13(1), 67-77.

Nurdin, N. (2017b). To Research Online or Not to Research Online: Using Internet-Based Research in Islamic Studies Context. Indonesian Journal of Islam and Muslim Societies, 7(1), 31-54.

Nurdin, N., \& Yusuf, K. (2020). Knowledge management lifecycle in Islamic bank: the case of syariah banks in Indonesia. International Journal of Knowledge Management Studies, 11(1), 59-80. https:// doi.org/10.1504/ijkms.2020 .105073

Pusyakhois Fifin Niya, Tinjauan Hukum Islam Terhadap Cerai di Luar Pengadilan Agama dan Implikasinya e-ISSN: 2715-4580 p-ISSN: 2715-8268 
pada Masyarakat Desa Penaruban Kecamatan Weleri Kabupaten Kendal. Di kota Kendal semarang, Institut Agama Islam Negeri Semarang

Peters A. G. dalam Soemitro Ronny Hanitijo, Study Hukum dan Masyarakat, Alumni, Bandung,1985Rasjid Sulaiman, Figh islam Sinar Buku Algerindo, 2007

Rifa'i Moh., Fiqih Islam Lengkap. Semarang: PT karya toha putra 1978

Rahardjo Satjipto. Pemanfaatan Ilmu Sosial Bagi Pengembangan Ilmu Hukum, Alumni, Bandung, 1977.

Rusli, Rusli, Islamic Feminism: Responsesof Muslim Feminists to Gender Inequality in Indonesia. Palu: Irshed Press, 2006.

Rusli, Rusli, "An Analysis of Islamic Feminism in Indonesia: Reconstruction of Islamic Legal Issues on Gender Relations," Hunafa: Jurnal Studia Islamika 3, no. 2 (2006): 1-12.

Rusli, Rusli, "Pendekatan Fenomenologi dalam Studi Agama: Konsep, Kritik dan Aplikasi," Islamica: Jurnal Studi Keislaman 2, no. 2 (2008): 141-153.

Rusli, Rusli. Nalar Fikih Tradisionalis Progresif: Analisis Terhadap Epistemologi Ibrahim Hosen. $1^{\text {st }}$ ed. Yogyakarta: Maghza Books, 2014.

Rusli, Rusli, "Hermeneutical Reading of Țalāq," HUNAFA: Jurnal Studia Islamika 12, no. 2 (2016): 209-229.

Rusli, Rusli, "The Role of Family in Preventing Social Conflikt in Societ From Islamic Perspectives," HUNAFA: Jurnal Studia Islamika 17, no. 1 (2020): 108-122.

Siraj Muhammad "Hukum Keluarga di Mesir dan Pakistan" dalam Islam,
Negara dan Hukum.Seri INIS XVI Kumpulan Karangan di Bawah Redaksi Johannnes den Heijer, Syamsul Anwar. Jakarta : INIS, 1993 Shokhi Muhammad Yalis b, Sanksi Hukum terhadap Talaq di Luar Pengadilan Agama, Studi Perbandingan Pandangan Akademisi Hukum Positif dan Akademisi Hukum Islam di Kota Malang. Malang. Tesis tidak di terbitkan.Universitas Islam Negeri Maulana Malik Ibrahim Malang.

Sukaenah, S., Rusli, R., \& B, M. T. (2020). The Effectiveness of Indonesia Supreme Court Regulation Number 1 Year 2016 Concerning Mediation of Marriage Disputes INTERNATIONAL JOURNAL OF CONTEMPORARY ISLAMIC LAW AND SOCIETY, 2(1), 63-80.

Syaifuddin Muhammad dkk, Hukum Perceraian Jakarta: Sinar Grafika, 2013

Syekh Zainudin ibnu Syekh Abdul Aziz, Fathul Mu"in, Alih Bahasa H. Ali As'ad, Al Hidayah, Surabaya, 1979.

Taufiq, Peradilan Keluarga Indonesia, Mahkamah Agung RI, Jakarta, 2001 Tihami H.M.A. dan Sahrani Sohari, Fikih Munahakat; Kajian Fikih Nikah Lengkap, cet.3, Jakarta: Rajawali Pers, 2013

Qodar Nurul, Perceraian di Luar Pengadilan pada Masyarakat Muslim Desa Sumberharjo Kecamatan Prambanan Kabupaten Sleman. Di kota Jogyakarta, Universitas Islam Negeri Suanan Kalijaga Jogyakarta 